\title{
KELIMPAHAN DAN KEPADATAN KIMA (Tridacnidae) DI KEPULAUAN SPERMONDE
}

\author{
Susiana*, Andiniarti Ningsih**, M. Anshar Amran** \\ *Mahasiswa Pascasarjan Faperik UNHAS-Makassar, e-mail: susiana_l21107001@yahoo.com \\ **Staf Pengajar Pascasarjana Faperik UNHAS-Makassar, $e$-mail :
}

\begin{abstract}
ABSTRAK
Kima (giant clams) merupakan salah satu hewan laut yang dilindungi di seluruh dunia termasuk di Indonesia. Penetapan tersebut berdasarkan kenyataan bahwa populasi kima di alam sudah sangat menurun terutama disebabkan pemanfaatan manusia. Melihat kondisi kritis tersebut, perlu dilakukan penelitian dasar tentang kelimpahan dan kepadatan kima dalam upaya konservasi. Penelitian bertujuan untuk menganalisis hubungan kelimpahan dan kepadatan terhadap parameter kualitas perairan di Kepulauan Spermonde. Lokasi penelitian hanya pada zona III dan IV di Kepulauan Spermonde. Metode penelitian menggunakan belt transect/sweept area pada dua stratifikasi yakni reff flat dan reef slope. Analisis data menggunakan formula Krebs (1978) dengan bantuan Software Microsoft Office Excel 2013 yang dapat memberikan gambaran kelimpahan dan kepadatan serta kualitas perairan antar zona. Hasil Penelitian menunjukkan bahwa Kelimpahan zona III dan zona IV adalah berturut-turut sebesar 75,5 dan 48,8 ind. Kepadatan zona III dan zona IV adalah berturut-turut sebesar 30,2 dan 19,4 ind/m². Jadi, baik kelimpahan maupun kepadatan kima zona III lebih tinggi dibandingkan dengan zona IV. Kelimpahan dan kepadatan tertinggi adalah dari jenis T. crocea. Sementara itu jenis-jenis lainnya yang diperoleh di lokasi adalah T. squamosa, T. maxima, T. derasa dan H. hippopus. Kelimpahan dan kepadatan kima dipengaruhi oleh nilai kualitas perairan yang mendukung kehidupan kima.
\end{abstract}

Kata Kunci: Kelimpahan, kepadatan, kima (Tridacnidae), dan Kepulauan Spermondesp

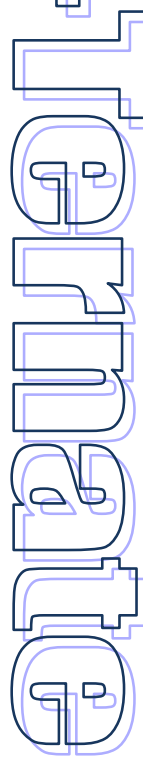

\section{PENDAHULUAN}

1.1. Latar Belakang

Kima termasuk dalam kelas Bivalvia, suatu kelompok hewan bertubuh lunak yang dilindungi sepasang cangkang bertangkup. Bernapas dengan insang yang bentuknya seperti lembaran yang berlapis-lapis. Alat gerak berupa kaki perut yang termodifikasi untuk menggali pasir atau dasar perairan. Beberapa jenis, melekatkan diri pada substrat berbatu dengan semacam rambut atau organ yang disebut byssus (Niartiningsih, 2007b).

Kerang raksasa (Bivalvia: Tridacnidae), salah satu kelompok dari populasi moluska yang terbesar di dunia, menghuni terumbu karang dangkal di wilayah Indo-Pasifik (Rosewater, 1965). Mereka memperoleh gizi dari saringan makanan (Klumpp et al., 1992), serta melalui hubungan simbiotik dengan ganggang dinoflagellata atau yang dikenal sebagai zooxanthella (Yonge, 1936, 1975 dalam Neo, 2009).

Kima (giant clams) merupakan salah satu hewan laut yang dilindungi di seluruh dunia termasuk di Indonesia. Sejak tahun 1983 CITES (Convention on International Trade In Endangered Species) mengelompokkan kima sebagai biota laut yang dilindungi yang ditindaklanjuti oleh Surat Keputusan Menteri Kehutanan No.12 tahun 1987, kemudian Undang-Undang No. 5 tahun 1990 yang dipertegas lebih lanjut dengan Surat Keputusan Menteri Kehutanan No. 31/KPTS - 11/1991 (Departemen Kehutanan, 1993 dalam 


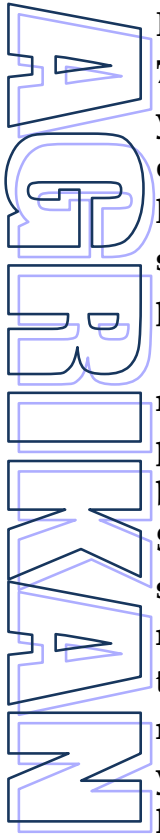

Niartiningsih, 2008). Peraturan Pemerintah No. 7 Tahun 1999 memasukkan ke tujuh jenis kima yang hidup di Indonesia menjadi hewan yang dilindungi. Penetapan tersebut berdasarkan kenyataan bahwa populasi kima di alam sudah sangat menurun terutama disebabkan pemanfaatan manusia (Ambariyanto, 2007).

Di Indonesia, secara umum kima kurang mendapat perhatian akan keberadaan populasinya di alam meskipun sudah termasuk biota yang dilindungi. Di Kepulauan Spermonde, kerang raksasa ini menjadi salah satu komoditas perikanan yang diburu oleh masyarakat nelayan karena harganya sangat tinggi sehingga populasi kima semakin menurun. Selain itu, informasi tentang spesies yang mengarah ke kegiatan untuk hewan langka ini masih sangat sedikit.

Beberapa hasil penelitian yang telah dilakukan belum memberikan gambaran populasi kima pada masing-masing zona di Kepulauan Spermonde, padahal informasi ini sangat penting untuk mengetahui lokasi, distribusi dan penyebaran kima yang sudah mengalami penurunan drastis dan sudah hampir punah. Oleh karena itu perlu dilakukan penelitian untuk mengetahui kelimpahan dan kepadatan kima di Kepulauan Spermonde. Dengan adanya informasi dasar ini, maka program konservasi kima dapat dilakukan secara efektif dan berkelanjutan.

\subsection{Tujuan dan Kegunaan}

Penelitian dilaksanakan dengan tujuan untuk menganalisis kelimpahan dan kepadatan terhadap parameter kualitas perairan di Kepulauan Spermonde.

Penelitian ini diharapkan dapat memberikan informasi mengenai kelimpahan dan kepadatan kima di Kepulauan Spermonde.

\section{METODE PENELITIAN}

\subsection{Waktu dan Tempat}

Penelitian dilaksanakan pada bulan September 2013 sampai dengan Januari 2014 di zona Kepulauan Spermonde Selat Makassar. Pengambilan sampel dilakukan pada dua zona yaitu zona III dan IV. Pada zona III pengambilan sampel diwakili oleh $P$. Sarappo, P. Sarappo Keke dan zona IV diwakili oleh P. Kondong Bali dan P.Kapoposang (Gambar 1.).
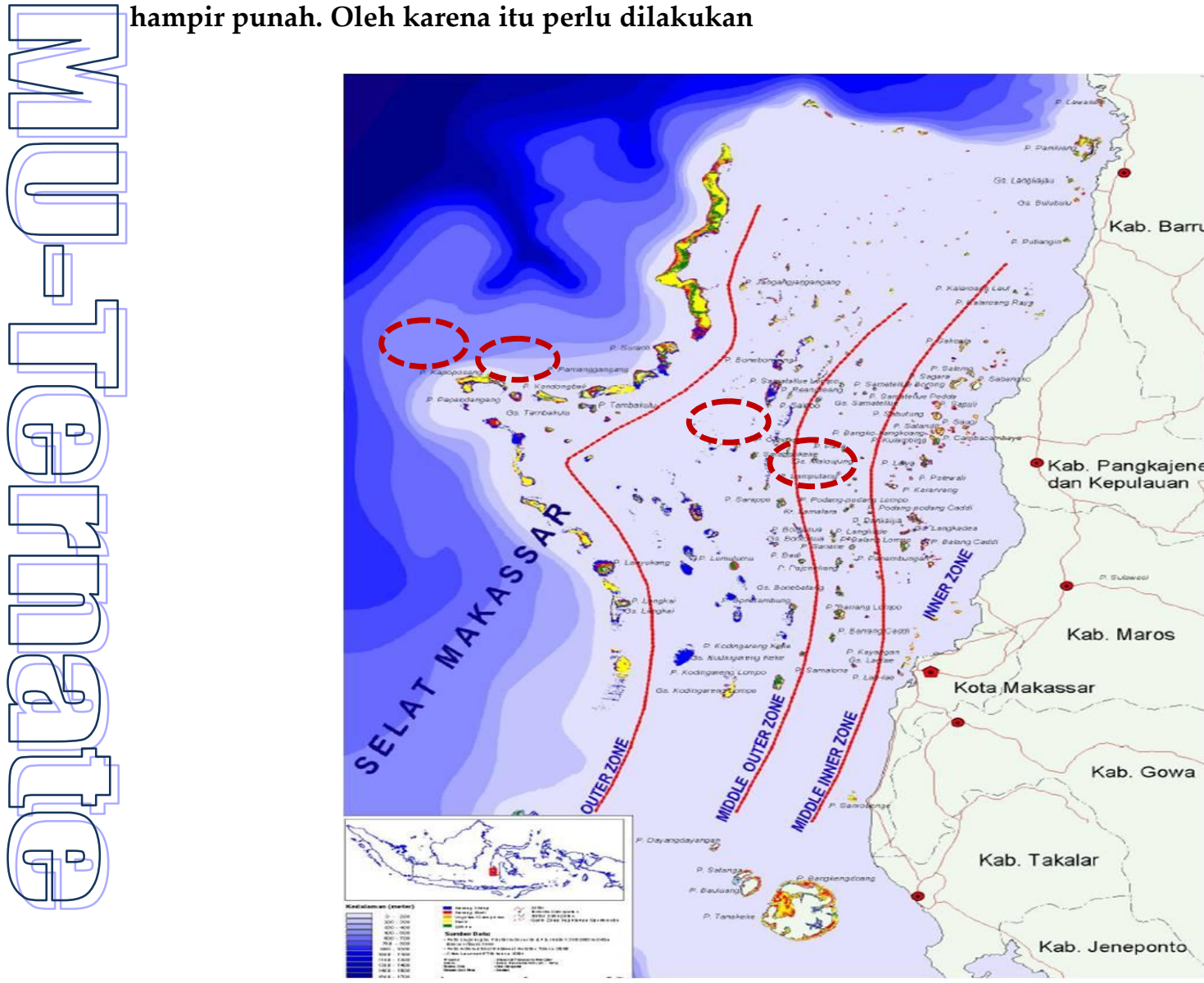

Gambar 1. Peta Lokasi Penelitian 


\subsection{Alat dan Bahan}

Alat dan bahan yang digunakan adalah sebagai berikut: untuk penentuan titik koordinat stasiun (zona) pengamatan digunakan GPS (Global Positioning System). Untuk dokumentasi penelitian menggunakan kamera under water. Dalam melakukan pengamatan kima akan digunakan peralatan menyelam (scuba, fins, masker, snorkel, papan pencatat, pensil dan penggaris). Untuk melaksanakan penelitian digunakan transportasi perahu motor.

Untuk mengukur data kualitas perairan yang terdiri dari salinitas, $\mathrm{pH}$, kekeruhan menggunakan peralatan digital Water Quality Chacker (WQC), untuk klorofil a, nitrat dan fosfat diambil sampel air untuk uji di Laboratorium Oseanografi Kelautan.

\subsection{Metode Kerja}

1. Penentuan Zona Pengamatan

Lokasi penelitian berada pada P. Sarappo, P. Sarappo Keke (middle outer zone), P. Kondong Bali dan P.Kapoposang (outer zone) di Kepulauan Spermonde. Masingmasing pulau ditentukan secara sengaja (purposive sampling) berdasarkan keberadaan terumbu karang dan habitat kima dari hasil penelitian-penelitian sebelumnya.

\section{Prosedur Pengambilan Data}

Pengambilan contoh air akan dilakukan pada pukul 8.00 sampai 16.00 Wita. Sampel akan diukur secara insitu. Untuk sampel yang perlu dianalisis lebih lanjut, akan diambil sampel air dan dibawa ke Laboratorium Kimia Oseanografi Fakultas Ilmu Kelautan dan Perikanan, Universitas Hasanuddin, Makassar.

Pengukuran kelimpahan kima akan dilakukan dengan penyelaman menggunakan metode sweept area (penyapuan wilayah). Metode ini juga disebut dengan belt transect, dimana penyelam mengamati biota target dalam luasan areal tertentu. Transek dibuat empat persegi panjang dengan menarik garis meteran sepanjang $100 \mathrm{~m}$.

Kemudian mencatat jumlah, ukuran dan identifikasi jenis-jenis kima yang ditemukan sepanjang transek dengan membatasi ruang amatan 2,5 m sebelah kiri dan 2,5 m sebelah kanan transek di setiap lokasi pengambilan sampel. Identifikasi jenis kima menggunakan buku FAO spesies identification guide for fishery purposes. The living marine resources of the Western Central Pacific. Volume 1. Seaweeds, corals, bivalves and gastropods (Carpenter, 1998).

Pengamatan populasi tiap jenis kima menggunakan belt transek, begitu juga dengan pengambilan contoh air yang dilakukan pada dua stratifikasi zona terumbu secara vertikal, yakni : zona rataan-tubir terumbu (reef flat-reef edge) dan zona lereng terumbu (reef slope).

\subsection{Pengolahan Data}

Data diolah dengan menggunakan program EXCEL 2013. Adapun analisis data meliputi:

a. Kelimpahan

Untuk mengetahui kelimpahan kima

digunakan rumus sebagai berikut:

Kelimpahan $=\mathbf{N}$

Dimana,

b. Kepadatan

$\mathrm{N}=$ jumlah keseluruhan individu kima sepanjang transek pengamatan

Untuk mengetahui kepadatan kima digunakan fomula menurut Krebs (1978), sebagai berikut :

$$
\mathrm{D}=\frac{\mathrm{Ni}}{\mathrm{A}}
$$

Dimana:

$\mathrm{D}=$ kepadatan individu (individu $\mathrm{m}^{-2}$ )

$\mathrm{Ni}=$ jumlah individu

A $=$ luas area pengamatan $\left(\mathrm{m}^{2}\right)$.

\section{HASIL DAN PEMBAHASAN}

Kelimpahan dan kepadatan individu kima pada 4 lokasi dihitung dalam $100 \mathrm{~m}^{2}$. Hasil penelitian menunjukkan bahwa kelimpahan individu kima pada zona 3 (P. Sarappo Lompo) lebih tinggi dibanding dengan Zona 4 (P. Kapoposang) yaitu 95 dan 83 individu. Hal ini terlihat pada Gambar 2. Demikian halnya dengan P. Sarappo Keke dan P. Kondong Bali, kelimpahan kima juga berbeda.

Kepadatan kima di zona III (P. Sarappo Lompo) lebih tinggi dari kepadatan di $P$. 
Kapoposang (zona IV) yaitu $38 \mathrm{ind} / \mathrm{m}^{2}$ dan 33,2 ind $/ \mathrm{m}^{2}$. Begitu pula halnya dengan $P$. Sarappo Keke dan P. Kondong Bali. Kepadatan tertinggi pada spesies $T$. crocea dan terendah pada $T$. derasa di setiap zona. Hal ini sesuai dengan habitat kima tersebut. Kepadatan tertinggi $T$. crocea juga diperoleh pada hasil penelitian Niartingsih (2013) di P. Kodingareng keke, $P$ Bone Tambu, P. Lumu-lumu, dan P. Badi (zona III). Begitu pula untuk zona IV (P. Langkai, P. Papandangang dan P. Lanjukang) lebih didominasi kepadatan jenis $T$. crocea.

Perbandingan kelimpahan dan kepadatan antar zona sangat signifikan (Gambar 3.). Kelimpahan zona III dengan zona IV adalah 75,5:48,8 sedangkan kepadatan zona III dengan zona IV adalah $30,2: 19,4 \mathrm{ind} / \mathrm{m}^{2}$. Jadi, baik kelimpahan maupun kepadatan kima zona
III lebih tinggi dibandingkan dengan zona IV. Kelimpahan dan kepadatan kima masingmasing zona pada stratifikasi reef flat lebih besar dibanding pada reef slope karena frekuensi kehadiran spesies lebih diminan di reef flat.

Pada zona III dan zona IV diperoleh 5 spesies kima yaitu T. crocea (Gambar 4.), $T$. maxima (Gambar 5.), T. squamosa (Gambar 6.), T. derasa (Gambar 7.) dan H. hippopus (Gambar 8.). Pada gambar 9. menunjukkan spesies $T$. crocea paling tinggi frekuensi kehadirannya di 4 lokasi penelitian sebesar $71 \%$. Hal ini sesuai dengan habitat $T$. crocea yang membenamkan seluruh tubuhnya di terumbu karang, hanya mantel saja yang terlihat dari atas sehingga sulit untuk diambil.
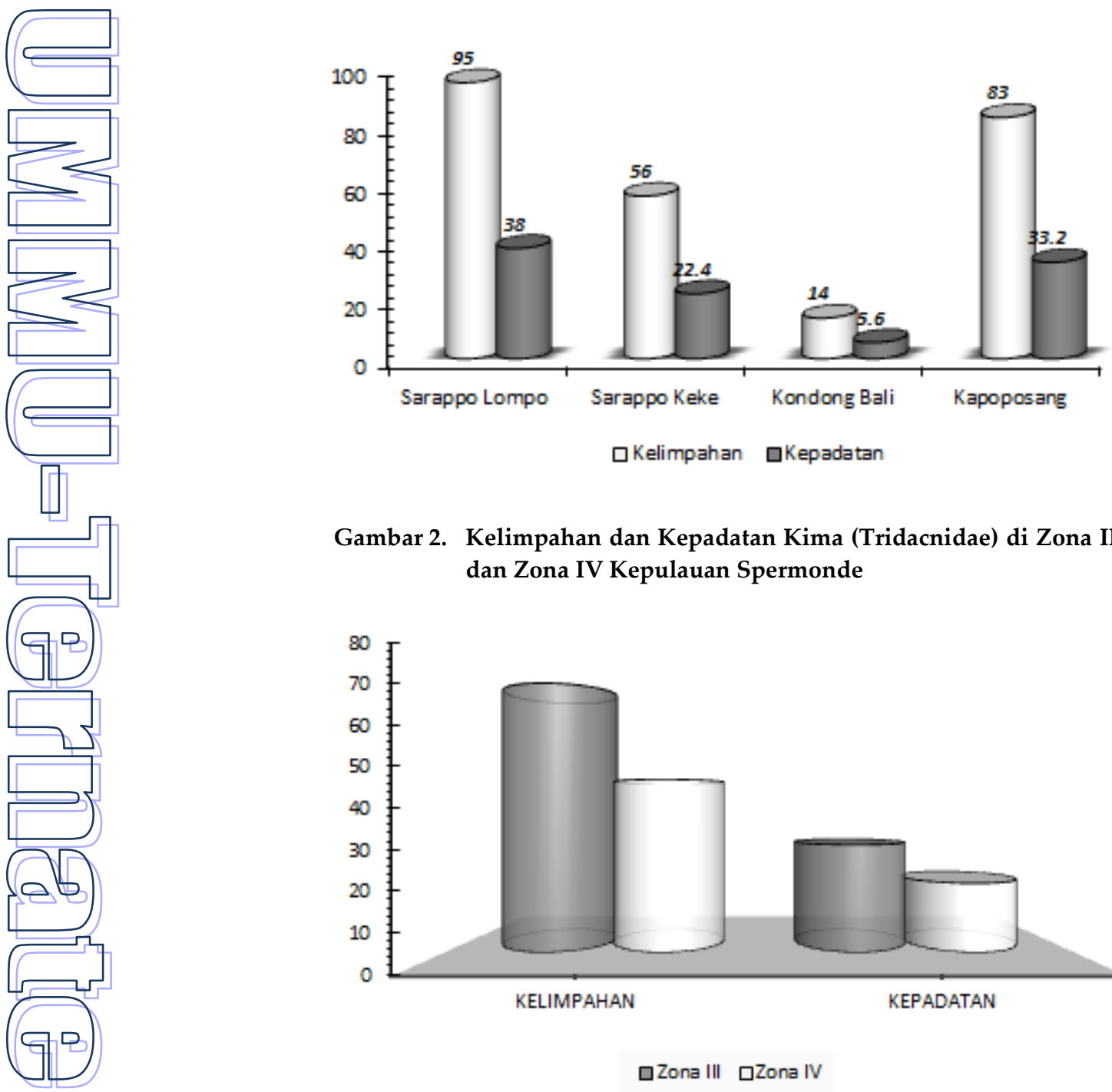

Gambar 2. Kelimpahan dan Kepadatan Kima (Tridacnidae) di Zona III dan Zona IV Kepulauan Spermonde

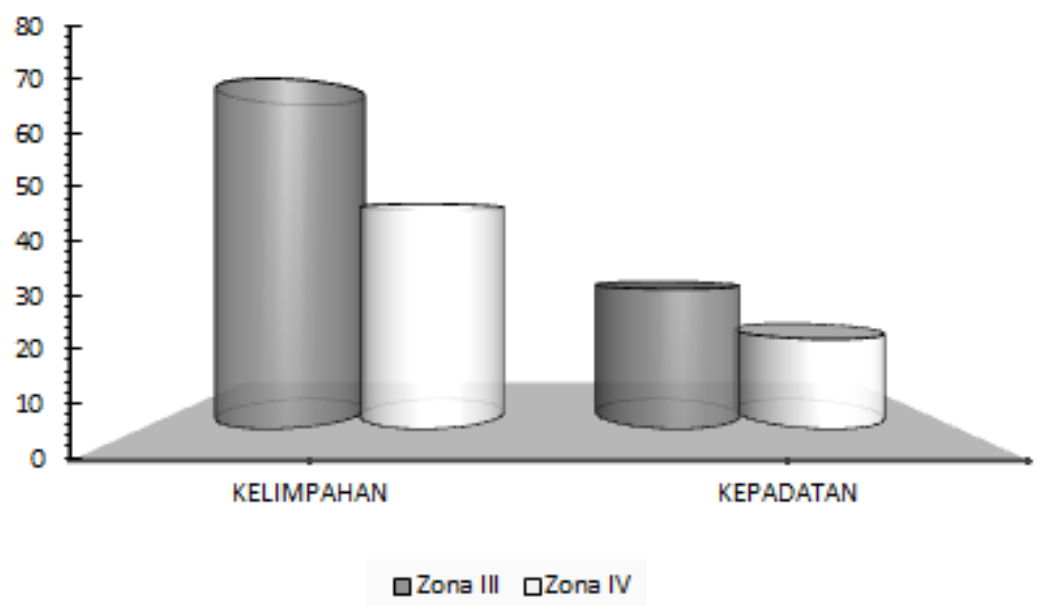

Gambar 3. Perbandingan Kelimpahan dan Kepadatan Kima antar Zona 


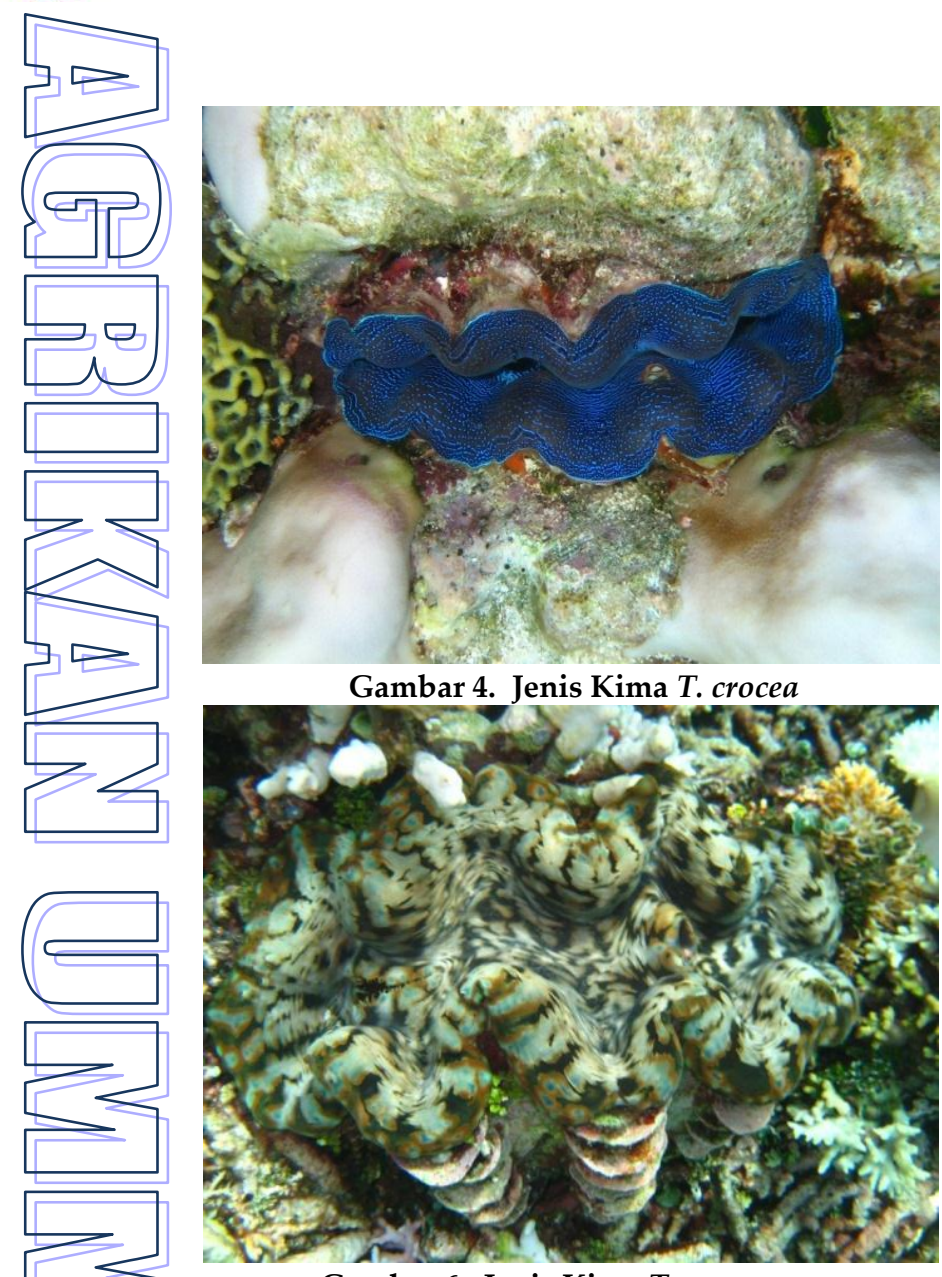

Gambar 6. Jenis Kima T. squamosa

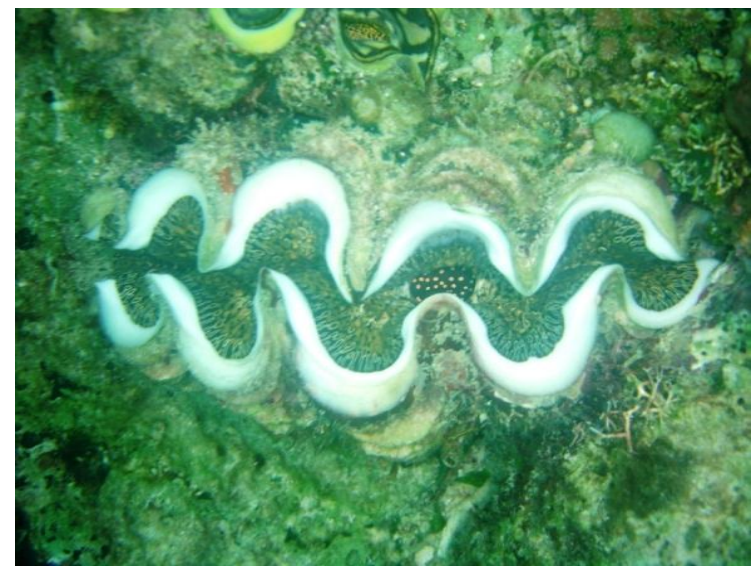

Gambar 5. Jenis Kima T. maxima

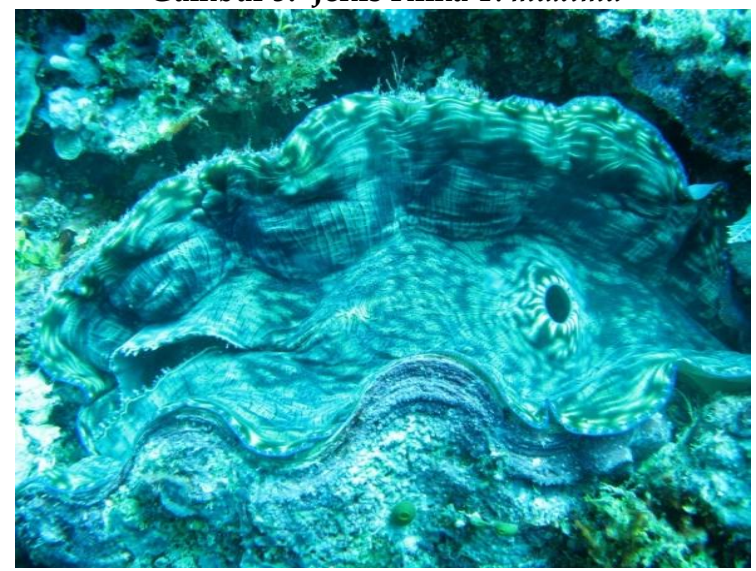

Gambar 7. Jenis Kima T. derasa

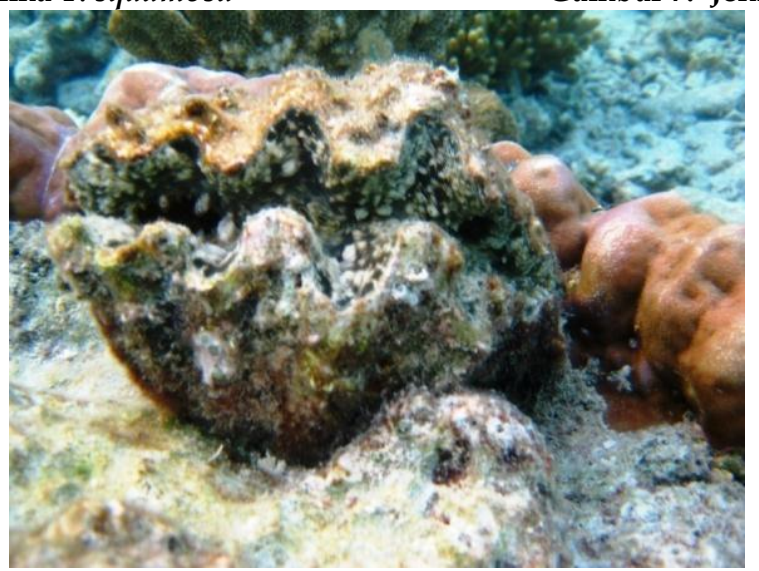

Gambar 8. Jenis Kima H. hippopus

Frekuensi kehadiran spesies yang paling rendah adalah $T$. derasa sebesar $1 \%$. Hal ini disebabkan karena eksploitasi berlebih sebelumnya seperti hasil laporan oleh Niartiningsih, et al., (2010) memperkuat indikasi semakin menurunnya populasi kima dari tiga spesies yang berukuran besar yaitu T.gigas, T.derasa dan H.porcelanus sudah tidak ditemukan lagi.
Data kualitas perairan yang mendukung kehidupan kima antara lain salinitas, $\mathrm{pH}$, kekeruhan, nitrat, posfat dan klorofil a (Gambar 10.).

Gambar 10 menunjukkan adanya perbedaan hasil kualitas perairan di zona III dan zona IV pada beberapa parameter seperti kekeruhan, nitrat, posfat dan klorofil a meskipun tidak begitu signifikan. Tingkat kekeruhan di zona III lebih rendah daripada di zona IV, hal ini 


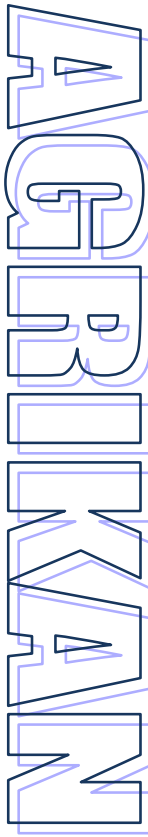

sesuai dengan kelimpahan dan kepadatan kima yang tinggi pula di zona III. Kima membutuhkan perairan yang jernih untuk kelangsungan hidupnya, karena berkaitan erat dengan kehidupan simbion kima yaitu zooxanthella yang membutuhkan cahaya matahari untuk proses fotosintesis. Hal ini diperjelas oleh Romimohtarto et al., (1987) dalam Niartiningsih (2012) yang mengatakan bahwa zooxanthella membutuhkan cahaya untuk berlangsungnya proses fotositesis sehingga ia membutuhkan perairan yang dangkal dan jernih.

Konsentrasi klorofil a di zona III juga lebih tinggi daripada di zona IV. Konsentrasi klorofil di suatu perairan dapat menggambarkan besarnya produktifitas primer disuatu perairan. Selain mendapatkan makanan melalui simbiosis,

makanan kima di alam adalah jazad renik berupa fitoplankton (Ludvianto, 1993 dalam Niartiningsih, 2012). Dalam inventarisasi dan pemetaan sumberdaya alam pesisir dan laut khlorofil-a digunakan untuk mengetahui keberadaan pitoplankton dalam air. Semakin tinggi konsentrasi khlorofil-a semakin berlimpah pitoplankton di air tersebut. (United State Environmental Protection Agency,http://seawifs. gsfc.nasa.gov/SEAWIFS.html dalam Bakosutanal, 2004).

Jadi, kelimpahan dan kepadatan dipengaruhi oleh nilai kualitas perairan. Semakin baik kualitas perairan yang mendukung kehidupan kima maka semakin tinggi kelimpahan dan kepadatan kima di suatu perairan.
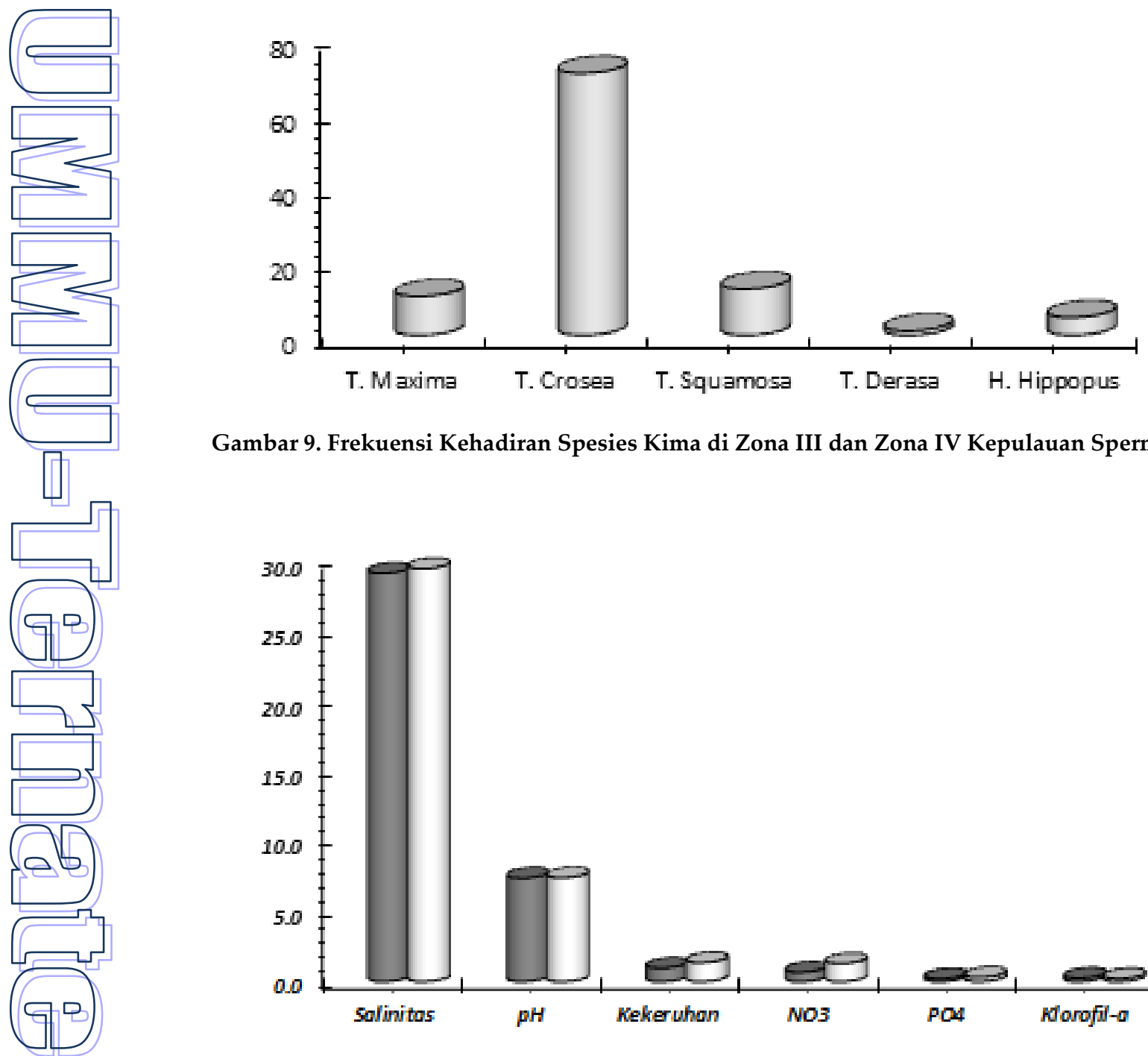

Gambar 9. Frekuensi Kehadiran Spesies Kima di Zona III dan Zona IV Kepulauan Spermonde

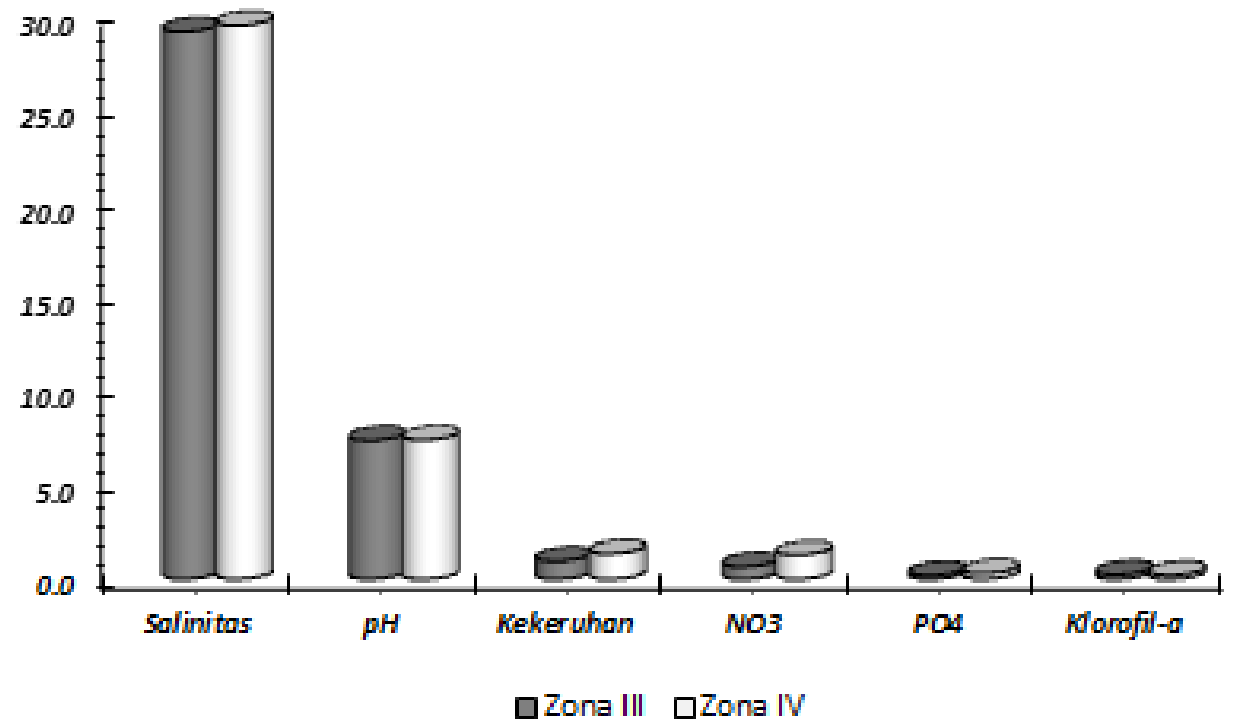

Gambar 10. Kualitas perairan di Zona III dan IV Kepulauan Spermonde 


\section{PENUTUP}

4.1. Kesimpulan

1. Berdasarkan hasil penelitian masing-masing lokasi bahwa populasi kima tersebar pada semua zona (Zona I dan Zona IV) di kepulauan Spermonde. Sebaran jenis-jenis kima terbatas pada zonasi habitat (reef flat dan reef slope).

2. Terdapat lima jenis kima yang tercatat di kepulauan Spermonde, yakni Tridacna crosea, T. maxima, T. squamosa, T. derasa, dan Hippopus hippopus. Jenis kima yang melekat pada batuan karang (karang batu) yakni $T$. crosea, $T$. squamosa dan T. maxima masih memiliki kelimpahan dan kepadatan individu yang tertinggi. Sedangkan jenis kima lainnya yang tidak melekat pada substrat memiliki kepadatan individu atau populasi yang rendah. Kepadatan kima pada habitat reef flat lebih besar dibanding pada reef slope.
3. Kelimpahan zona III dengan zona IV adalah 75,5:48,8 sedangkan kepadatan zona III dengan zona IV adalah $30,2: 19,4 \mathrm{ind} / \mathrm{m}^{2}$. Jadi, baik kelimpahan maupun kepadatan kima zona III lebih tinggi dibandingkan dengan zona IV.

4. Kondisi kualitas perairan umumnya bagus pada masing-masing zona, namun terdapat perbedaan yang tidak terlalu signifikan. Kelimpahan dan kepadatan zona III dan zona IV dipengaruhi oleh nilai kualitas perairan. Semakin baik kualitas perairan yang mendukung kehidupan kima maka semakin tinggi kelimpahan dan kepadatan kima di suatu perairan.

\subsection{Saran}

Agar dilakukan penelitian lanjutan mengenai populasi kima dan keterkaitannya dengan faktor oseanografi lainnya yang mendukung kehidupan populasi kima.

\section{DAFTAR PUSTAKA}

Ambariyanto. 2007. Pengelolaan Kima di Indonesia: Menuju Budidaya Berbasis Konservasi. Seminar Nasional Moluska: dalam Penelitian, Konservasi dan Ekonomi Jurusan Ilmu Kelautan, FIKP UNDIP, Semarang, 17 Juli 2007.

Bakosurtanal. 2004. Sebaran Chlorophyll - a di Perairan Indonesia Skala $1: 1.000 .000$. Pusat Survei Sumberdaya Alam Laut Badan Koordinasi Survei dan Pemetaan Nasional.

Carpenter, K.E., Niem, V.H. (eds). FAO spesies identification guide for fishery purposes. The living marine resources of the Western Central Pacific. Volume 1. Seaweeds, corals, bivalves and gastropods. FAO, Rome.

Neo, M. L., P. A. Todd, S. L.-M. Teo and L. M. Chou. 2009. Can artificial substrates enriched with crustose coralline algae enhance larval settlement and recruitmentin the fluted giant clam (Tridacna squamosa)?. Hydrobiologia. 625:83-90

Niartiningsih, A., S. Yusuf dan I. Andriani. 2007b. Keragaman dan Hubungan Kekerabatan Kima (Tridacnidae) di Kepulauan Spermonde: Suatu Upaya Konservasi dan Perbaikan Mutu Benih. Makalah. Disampaikan pada Seminar Nasional Genetika, Breeding dan Bioteknologi Perikanan. Bali, 12 November 2007.

Niartiningsih, A. M. Litaay, E. Suryati dan I. Prasetiawan. 2008. Pemeliharaan Juvenil Kima Sisik (Tridacna Squamosa) dan Lola (Trochus Niloticus) secara Monokultur dan Polikultur pada Kedalaman Berbeda di Perairan Pulau Badi, Kabupaten Pangkep. Prosiding Simposium Musyawarah NasionalTerumbu Karang II.

Niartiningsih,A., Syafiuddin dan S.Yusuf, 2010. Inventarisasi Potensi Biota Laut Langka Kima (Tridacnidae) di Kepulauan Spermonde. Laporan Hasil Penelitian Hibah Kompetitif Penelitian Strategis Nasional, Dirjen Dikti.

Niartiningsih, A., 2012. Kima, Biota Laut Langka: Budidaya dan Konservasinya. Identitas Universitas Hasanuddin. Makassar

Niartiningsih, A. S. Yusuf dan M. A. Amran, 2013. Pemetaan Populasi Biota Langka Kima (Tridacnidae) dan Upaya Konservasi melalui Perbaikan Mutu Benih untuk Restocking. Laporan Penelitian Strategis Nasional (Stranas), Dirjen Dikti. 


\title{
BENTUK PENGELOLAAN HUTAN DENGAN KEARIFAN LOKAL MASYARAKAT ADAT TUGUTIL
}

(Studi Kasus Masyarakat Adat Tugutil di Dusun Tukur-tukur Kecamatan Wasile Timur Kabupaten Halmahera Timur)

\author{
Sabaria Niapele \\ Staf Pengajar FAPERTA UNIV. NUKU-Tidore, $e$-mail: -
}

\begin{abstract}
ABSTRAK
Masyarakat adat memiliki motivasi yang kuat dalam melindungi hutan dibandingkan pihak-pihak lain karena menyangkut keberlanjutan kehidupan mereka, pengetahuan asli yang dimiliki bagaimana memelihara dan memanfaatkan sumberdaya hutan yang ada di dalam habitat mereka. Memiliki hukum adat untuk ditegakkan serta memiliki kelembagaan adat yang mengatur interaksi harmonis antara mereka dengan ekosistem hutannya. penelitian ini bertujuan untuk mengetahui bentuk-bentuk kearifan lokal dalam mengelola hutan. untuk mengetahui bagaimana cara dalam memelihara dan mempertahankan kearifan lokalnya dalam mengelola hutan dan pemanfaatan tumbuhan hutan. Penelitian dilaksanakan di Dusun Tukur-Tukur Kecamatan Wasile Timur Kabupaten Halmahera Timur. Metode penelitian yang digunakan adalah eksplorasi deskriptif dan pengambilan data dengan metode random sampling dan metode trigulasi. Data dianalisis dengan metode deskriptif kualitatif. Berdasarkan hasil penelitian maka dapat diketahui bentuk-bentuk kearifan lokal masyarakat adat tugutil antara lain sebagai berikut : Larangan merusak sagu raja, Buko, Nonaku, Ma ngadodo gomu pahiyara (batasan pemeliharaan). untuk memelihara dan mempertahankan kearifan lokal dalam mengelola hutan adalah dengan cara sebagai berikut: Penuturan lisan, Sangsisangsi adat, Penerapan secara langsung (praktek). ada terhadap 149 tumbuhan yang dimanfaatkan. yang dibagi atas 100 tumbuhan bahan pangan (71 spesies)dan 49 sumber tumbuhan obat (45 spesies).
\end{abstract}

Kata Kunci: Kearifan Lokal, Pengelolaan hutan, Lingkungan

\section{PENDAHULUAN}

\subsection{Latar Belakang}

Luas wilayah indonesia yang mencapai 195 juta hektar, diataranya $65 \%$ atau sekitar 144,0 juta hektar merupakan kawasan hutan. Dengan demikian, di Negara Indonesia sumber daya hutan menjadi potensi kekayaan alam yang sangat penting, sebab berfungsi sebagai pengatur tata guna air, perlindungan terhadap erosi tanah dan lingkungan, serta mengandung berbagai sumber daya alam yang pontensial bagi pembangunan nasional.

Hutan diidentifikasikan sebagai suatu lahan yang sangat luas ditumbuhi oleh pohonpohon secara keseluruhan merupakan persekutuan hidup alam hayati beserta lingkungannya dan ditetapkan oleh pemerintah sebagai hutan (UU 41 Thn. 1999).

Bagian terbesar dari sebuah ekosistem ialah kumpulan tetumbuhan dan binatang yang secara bersama-sama dan otomatis membentuk suatu masyarakat tumbuhan dan binatang yang dinamakan komunitas. (Resosoedarmo dkk.1989).

Komunitas terdiri atas berbagai organisme yang saling berhubungan pada suatu daerah tertentu. Kesatuan dari berbagai jenis organisme itu bisa menjadi perwakilan dari suatu tipe komunitas ataupun ekosistem tertentu yang memmiliki karakteritik tertentu 


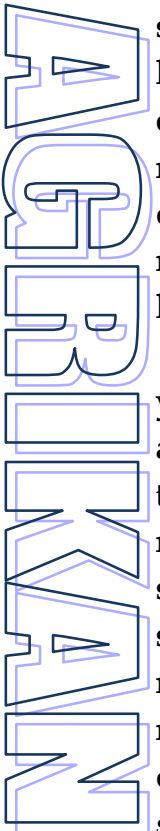

sehingga menjadi pembeda antara satu komunitas ekosistem dengan komunitas dan ekosistem lainnya. Keanekaragaman hayati merupakan sumber daya alam yang dapat dimanfaatkan untuk berbagai keperluan manusia dengan melihat kaidah-kaidah kelestarian hutan.

Hubungan masyarakat asli atau lokal yang dekat dengan lingkungan sumber daya alam membuat mereka memiliki pemahaman tersendiri terhadap sistem ekologi dimana mereka tinggal. Lingkungan sendiri seharusnya dipersepsikan bukan hanya sekedar sebagai objek yang harus digunakan untuk memenuhi kebutuhan manusia (human centris), melainkan juga harus dipelihara dan ditata demi kelestarian lingkungan itu sendiri (eco sentris). Oleh karena itu, adanya ikatan antara manusia dengan alam akan melahirkan pengetahuan dan pikiran bagaimana mereka memperlakukan alam lingkungannya. Mereka menyadari betul akan segala perubahan dalam lingkungan sekitarnya dan mampu mengatasinya demi kepentingannya. Salah satu cara ialah dengan mengembangkan sikap kelakuan, gaya hidup, dan tradisi-tradisi yang mempunyai implikasi positif terhadap pemeliharaan dan pelestarian lingkungan hidup (Salim, 1979). Tradisi - tradisi inilah yang disebut sebagai salah satu aplikasi sebuah kearifan lokal.

Masyarakat adat dalam tradisi modern dikenal dengan istilah "indigenous society", yang secara harafiah berarti seseorang yang di anggap memiliki keaslian kehidupan. Adat dapat diartikan "pribumi" digunakan semata-mata sebagai suatu kata sifat, orangorang yang berasal dari suatu kultur atau kelompok menghormati asal usul mereka dengan perasaan, pemaknaan dan pengertian yang mendalam atas suatu wilayah yang mereka tempati. Masyarakat adat memiliki karakter yang membatasi diri dan mengidentikan diri mereka sebagai sebuah kelompok kecil yang memiliki otoritas dalam menempati sebuah wilayah tertentu berdasarkan ukuran-ukuran yang disepakati secara konvensional (Aman, 2008).

Keberadaan masyarakat adat tersebar di berbagai penjuru Nusantara dengan keragaman ekosistem tempat mereka hidup. Mayoritas masyarakat adat mewarisi tanah ulayat milik nenek moyang mereka dengan sistem hidup yang terkadang sangat ketat diberlakukan. Pedalaman hutan hujan tropis, pinggiran hutan dan sepanjang garis pantai adalah beberapa lokasi dimana masyarakat adat tinggal, menetap permanen, nomaden dan semi nomaden. Sehingga kita boleh menyimpulkan bahwa selama ini, $30 \%$ hutan asli Indonesia dijaga dan dilestarikan oleh Masyarakat Adat. Selama waktu itu pula muncullah kecerdasan dan local spirit bagaimana kita mengelola dan melesatarikan sumber daya alam khususnya sumber daya hutan yang dimiliki Indonesia. Masyarakat adat merupakan suplemen dari Negara Indonesia, bukan komplemen.

Masyarakat adat memiliki motivasi yang kuat dalam melindungi hutan dibandingkan pihak-pihak lain karena menyangkut keberlanjutan kehidupan mereka, pengetahuan asli yang dimiliki bagaimana memelihara dan memanfaatkan sumberdaya hutan yang ada di dalam habitat mereka. Memiliki hukum adat untuk ditegakkan serta memiliki kelembagaan adat yang mengatur interaksi harmonis antara mereka dengan ekosistem hutannya.

Masyarakat adat Togutil memiliki pola kehidupan secara nomaden, dan karena itu kehidupan mereka masih sangat tergantung pada keberadaan hutan-hutan asli. Pada umumnya mereka bermukim secara berkelompok di sekitar sungai Dodaga dan memiliki wilayah teroterial kekuasaan yang masing-masing kelompok saling menghormati wilayah Teroterial masing-masing kelompok. Rumah-rumah mereka terbuat dari kayu, bambu dan beratap daun palem sejenis Livistonia sp. Umumnya rumah mereka tidak berdinding dan berlantai papan panggung.

Walaupun mereka masih primitif karena pola hidup secara nomaden tanpa merubah dan merusak alam, namun keberadaan mereka seperti itu telah memberikan pelajaran berharga kepada kita semua dalam hal melestarikan hutan. Seakan-akan mereka berpesan; janganlah sekali-kali merusak alam (Latif, 2009).

Dalam pandangan masyarakat adat Tugutil bahwa tumbuh-tumbuhan pada dasarnya perlu dan ingin diperhatikan atau diperlakukan secara baik. Karena diyakini 
bahwa perlakuan yang baik terhadap tumbuhan yang dimanfaatkan maka setiap tumbuhan yang dipelihara akan memberikan keuntungan dan kenyamanan bagi manusia. Merusak atau memanfaatkan secara berlebihan berarti akan merusak sumber kehidupan yang dimiliki sehingga akan menyulitkan kehidupan anak cucu (ngofa ngofaka). Pada umumnya masyarakat adat Tugutil telah mengetahui dan memanfaatkan berbagai jenis tumbuh-tumbuhan untuk kelangsungan hidupnya sehari-hari. Berangkat dari pentingnya penerapan kearifan lokal dalam menjaga kelestarian lingkungan oleh masyarakat adat maka dari Gambaran ini yang mendasari perhatian dan pemikiran penulis untuk melakukan penelitian dengan judul "Bentuk Pengelolaan Hutan Dengan Kearifan Lokal Masyarakat Adat Tugutil (Studi Kasus Masyarakat Adat Tugutil di Dusun Tukur Tukur Kecamatan Wasile Timur Kabupaten Halmahera Timur).

1.2. Tujuan dan Manfaat Penelitian

1.3.1. Tujuan Penelitian

1. Mengetahui Bentuk-bentuk kearifan lokal yang ada pada masyarakat adat Tugutil di Dusun Tukur-tukur dalam mengelola hutan?

2. Mengetahui bagaimana masyarakat adat Tugutil di Dusun Tukur-tukur dalam memelihara dan mempertahan kearifan lokalnya dalam mengelola hutan?

3. Mengetahui jenis-jenis tumbuhan yang dimanfaatkan oleh masyarakat adat Tugutil di Dusun Tukur-tukur?

1.3.2. Manfaat Penelitian

1. Dari segi akademis, Hasil yang diperoleh dari penelitian ini juga diharapkan dapat menjadi salah satu sumber informasi dan bahan acuan untuk melakukan penelitianpenelitian selanjutnya yang berkaitan dengan masyarakat adat tugutil.

2. Dari segi sosial, dapat diperoleh penjelasan mengenai lingkungan masyarakat setempat dan seberapa jauh kelestarian sumber daya alam dipengaruhi oleh kearifan lokal masyrakat setempat.

3. Dari segi praktis, Hasil penelitian ini di harapkan dapat dijadikan sebagai bahan pertimbangan dan masukan bagi pemerintah setempat dalam menentukan suatu kebijakan yang tepat dalam hal pengembangan dan memperdayakan masyarakat adat Tugutil ke depan.

\section{METODE PENELITIAN}

\subsection{Waktu dan Tempat Penelitian}

Penelitian ini dilaksanakan pada bulan Januari - April 2013. Di Dusun Tukur-tukur Kecamatan Wasile Timur Kabupaten Halmahera Timur .

\subsection{Alat dan Bahan}

Alat dan bahan yang digunakan dalam penelitian ini antara lain :

1. Kamera digital untuk mendokumentasikan Kegiatan penelitian.

2. Alat tulis menulis untuk mencatat data di lapangan.

3. Panduan Kuisioner yang digunakan sebagai bahan acuan dalam pengumpulan data melalui proses wawancara terhadap responden (Masyarakat adat dimana bahasa yang digunakan disesuaikan).

\subsection{Obyek penelitian}

Kelompok masyarakat adat Tugutil yang berada di dusun tukur-tukur Kecamatan Wasile Timur Kabupaten Halmahera Timur.

\subsection{Metode Penelitian}

Adapun metode yang digunakan metode penelitian yang digunakan adalah eksplorasi deskriptif, dengan pertimbangan bahwa untuk dapat mendokumentasikan pengetahuan masyarakat tentang bentukbentuk kearifan lokal, cara mempertahakan kearifan lokal dan pengelolaan tumbuhtumbuhan pangan dan obat-obatan membutuhkan penggalian informasi yang tepat dan kajian cermat dan mendalam.

\subsection{Jenis dan Sumber Data}

Data primer merupakan data yang diperoleh dari masyarakata adat Tugutil dengan metode penentuan sampel dari jumlah masayarakata adat Tugutil serta menggunakan panduan quesioner. Sementara data sekunder data yang diambil dari instansi terkait yang berkaitan dengan penelitian ini. 